\title{
Genetic Diversity Analysis Based on Molecular Level in Selected Brassica compestris L. var. toria Genotypes
}

\author{
J.L. Salam ${ }^{1 *}$, N. Mehta $^{2}$, A.K. Sarawagi ${ }^{2}$, Ritu R. Saxena ${ }^{2}$, S. Verulkar and N. Tomar ${ }^{3}$ \\ ${ }^{I}$ S.G. College of Agriculture and Research Station, Jagdalpur 494005 Chhattisgarh, India \\ ${ }^{2}$ College of Agriculture, Raipur IGKV, Raipur 494012 Chhattisgarh, India \\ ${ }^{3}$ College of Horticulture, Rajnandgaon Chhattisgarh, India
}

*Corresponding author

\section{A B S T R A C T}

\section{Keywords}

Brassica

compestris,

Toria,

Genetic diversity

Article Info

Accepted:

26 June 2018

Available Online:

10 July 2018
The present study was carried out at Dr R.H. Richharia Research Laboratory, Department of plant molecular biology and biotechnology, College of Agriculture Raipur (C.G.), Indira Gandhi Krishi Vishwavidyalaya, Raipur (Chhattisgarh) during Rabi 2013-14. Experimental materials comprised 24 Brassica compestris L. var. toria genotypes with the objectives to estimate the genetic diversity analysis at molecular level. The present investigation genetic diversity at molecular level in 24 genotypes of toria, two major cluster with $53 \%$ genetic similarity in which two genotypes named GPT-13 and GPT-59 comes under one cluster and remaining 22 falls under second cluster. Genotypes GPT-1 and GPT-43 and genotype GPT125 and GPT-126 exhibited 87\% genetic similarity with each other. These results indicated the existence of sufficient Variability among genotypes and there are very much chance of improvement either through selection or through hybridization by getting heterosis.

\section{Introduction}

Rapeseed-Mustard group of crops is among the oldest cultivated plants in human civilization. Biologically, the rapeseed and mustard plants belongs to the family Crucifarae and under the genus Brassica with large number of species and sub species cultivated in India. The word 'rape' and 'mustard' have been derived from the word rapum meaning turnip and European practice of mixing the sweet 'must' of old wine with crushed seeds of black mustard (Brassica nigra (L.) Koch) to form a hot paste, respectively.

Rapeseed mustard crops in India comprise traditionally grown indigenous species namely toria (Brassica campestris L.var. toria), brown sarson (Brassica campestris L. var. brown sarson), yellow sarson (Brassica campestris L. var yellow sarson), Indian mustard (Brassica juncea L. Czern and Coss), black 
mustard (Brassica nigra) and taramira (Eruca sativa Mill), which have been grown since about $3500 \mathrm{BC}$ along with non-traditional species like gobhi sarson (Brassica napus L.) and Ethopian mustard or Karan rai (Brassica carinata A. Braun) (Chouhan et al., 2011). The rapeseed-mustard group is comprised of two distinct type (i) self pollinated - Indian mustard, raya and yellow sarson of which Indian mustard is the most important member of the group accounting for 75-80 per cent of the area under rapeseed-mustard and (ii) cross pollinated - brown sarson, toria and taramira.

Among rapeseed-mustard group toria is an important oilseed considered as a catch crop in early rabi season of India. Toria has a relatively dwarf plant frame, short duration (70-80 days), small seeded siliquae and mature early and susceptible to aphids, alternaria blight and frost. Toria seeds are spherical or ovoid in shape and are reddish or dark brown in colour, having slightly wrinkled surface. Seeds are slightly smaller than those of mustard. It is cultivated largely in Assam, Bihar, Orissa and West Bengal mainly as winter crop. In Chhattisgarh the productivity of toria is very low comparable to the national productivity and other states like Haryana (1609 kg), Gujrat (1577 kg), Rajshthan (1187 $\mathrm{kg}$ ), Uttar Pradesh (1125 kg) and Madhya Pradesh $(1108 \mathrm{~kg})$ etc. The reasons for low productivity of toria due to local genotypes which have low yielder, dwarf in nature, bushy or trailing habit and susceptible to alternaria blight, powdery mildew and aphids etc. This results in a big gap between requirement and production of rapeseed and mustard in Chhattisgarh and India.

Molecular markers provided an important tool for the genetic diversity study of Indian and Chinese oilseed mustard. All Indian accessions grouped together as assayed by random amplified polymorphic DNA (RAPD) (Jain et al., 1994; Khan et al., 2008). As assayed by amplified fragment length polymorphism (AFLP) markers, all the Indian and Chinese $B$. juncealines were clustered together whereas lines from other sources formed another group (Srivastava et al., 2001). RAPD analysis indicated that the genetic relationship of Chinese oilseed mustard accessions was mainly decided by the specific ecological environment as well as the local cultivation customs and high diversity of B. juncea was discovered in south-western and western China (Puet et al., 2007). This is supported by the analysis using AFLP, sequence-related amplified polymorphism (SRAP) and simple sequence repeat (SSR) markers ( $\mathrm{Xu}$ et al., 2008). Analysis using SRAP markers revealed that the Chinese oilseed mustards were divided into different groups mainly according to their growth habitat (Wu et al., 2009). SSR allelic diversity in the A genome and B genome supported a polyphyletic origin and secondary centres of genetic diversity of oilseed B. juncea in China and India (Sheng et al.)

In Chhattisgarh, large number of local toria germplasm is available. Hence, local genotypes of toria can be upgraded by crossing with improved varieties. This will lead to the higher yield and oil content in local genotypes of toria along with good adaptation.

\section{Materials and Methods}

The present study entitled "Genetic diversity analysis based on molecular level in selected Brassica compestris L. var. toria genotypes" was carried out at Dr R.H. Richharia Research Laboratory, Department of plant molecular biology and biotechnology, College of Agriculture Raipur (C.G.), Indira Gandhi Krishi Vishwavidyalaya, Raipur (Chhattisgarh) during Rabi 2013-14. Experimental materials comprised 24 Brassica compestris L. var. toria genotypes with the objectives to estimate the genetic diversity analysis at molecular level. 


\section{Genomic DNA isolation}

DNA was isolated by modified CTAB method of DNA extraction for Rapeseed as suggested by Jonathan and Wendel (1990).

The leaf bits were cut in an eppendrof tube. Added $700 \mu \mathrm{l}$ CTAB buffer in this and kept it at $4^{0} \mathrm{C}$ for 3-4 hrs. Grinded the leaf and added some more CTAB buffer. Kept it in water bath at $65^{\circ} \mathrm{C}$ for $20 \mathrm{~min}$. Added $700 \mu \mathrm{l}$ of chloroform: isoamyl alcohol (24:1). Then vortex the sample. Centrifuged it for $20 \mathrm{~min}$. at $14000 \mathrm{rpm}$. Transferred the upper clear layer in new $1.5 \mathrm{ml}$ Eppendrof tube (Repeat twice from the step 5-8). Added $175 \mu \mathrm{l}$ of $3 \mathrm{M}$ sodium acetate and $400 \mu$ of ice cold isopropanol in this and kept it for incubation at $-20^{\circ} \mathrm{C}$ for overnight. Centrifuged at $14000 \mathrm{rpm}$ for $20 \mathrm{~min}$. and discarded the supernatant. Then washed the pellet with $70 \%$ ethanol (50 $\mu 1)$. Centrifuged it for $10 \mathrm{~min}$. Air dried the pellet. Added $100 \mu \mathrm{l}$ of TE buffer and dissolved the pellet.

\section{DNA quantification}

The concentration and quality of the genomic DNA sample were estimated on spectrometer ND-2000 (Nanodrop, USA). Finally, all the genomic DNA samples were diluted to a final concentration of $40 \mathrm{ng} / \mu \mathrm{l}$ with autoclaved distilled water and stored at $-20^{\circ} \mathrm{C}$ for further use.

\section{PCR amplication of ISSR markers}

A total of 4 ISSR primers of toria were used in this study. Polymerase chain reaction (PCR) for amplification of DNA preparation was carried out in a $25 \mu \mathrm{l}$ for ISSR. All PCR reaction were carried out in a Veriti Thermal Cycler-96 mells (Applied Biosystem, USA). PCR products were separate using 5\% PAGE, stained with ethidium bromide and photographed under UV light using Image Gel
Doc software Version 2.0.1(Bio-Rad, USA)

\section{Data analysis}

The band profiles were scored only for distinct, reproducible bands as present (1) or absent (0) for each ISSR primer pair. Jaccard's similarity coefficient values were calculated and dendrogram based on similarity coefficient values were generated using unweighted pair-group method with arithmetic mean (UPGMA) by the NTSYSpc 2.10e software (Rohlf, 2000). The polymorphism information content (PIC) value of ISSR markers was calculated using the following formula (Anderson et al., 1993).

$\mathrm{PIC}=1-\sum_{i=1}^{k} P i 2$

Where $\mathrm{k}$ is the total number of alleles (bands) detected for one ISSR locus and $\mathrm{P}_{1}$ is the frequency of the $\mathrm{i}^{\text {th }}$ allele (band) in all the samples analyzed.

\section{Results and Discussion}

Genetic diversity on the molecular markers in selected toria genotypes

Four ISSR primers were used to study the genetic diversity among twenty four genotypes (Fig. 1 and 2). All were showed polymorphic. The similarity coefficient ranged from 0.53 to 0.87 . Turi et al., (2012) at Peshawar, Pakistan investigated genetic diversity among 120 different accessions of Brassica species were characterized with the help of SSR markers. 39 SSR primers were used and they produced 162 scorable bands in which 105 were polymorphic. The average rate of polymorphic loci was $46 \%$, which indicates high genetic diversity among the accessions. The UPGMA cluster analysis revealed two main clusters and nine subclusters. The dandogram indicated that based on above maker study formed two major clusters namely ' $A$ ' and 'B'. Two genotypes named GPT-13 and GPT-59 comes under one 
cluster 'A' with $53 \%$ genetic similarity while, remaining 22 genotypes falls under second cluster B with $66 \%$ genetic similarity. Shiran et al., (2004) at studied Shahre Kord, Iran the genetic diversity among twenty seven rapeseed (Brassica napus) cultivars and one cultivar of Brassica rapa was investigated using Random Amplified Polymorphic DNA (RAPD) molecular marker. A set of twenty four ten-mer arbitrary primers was used which produced reliable polymorphic DNA bands ranging in molecular weight from 440 to 3299 bp. A total of 133 polymorphic bands out of 173 reproducible bands were obtained. Genetic similarity matrix based on Jaccard's index detected coefficient ranging from 0.38 to 0.78 . Coefficients were used to contrast a dendrogram using unweighted paired group of arithmetic mean (UPMGA) algorithm. Cultivars were clustered into two major groups.
In major cluster ' $\mathrm{B}$ ' showed two sub-clusters as 'B1' and 'B2' near the $70 \%$ similarity level. Genotypes GPT-1 with GPT-43 and genotype GPT-125 with GPT-126 exhibited 87\% genetic similarity with each other. Genotype PT 507, PT 30 and GPT-48, GPT-54 exhibited $79 \%$ genetic similarity. Hasan et al., (2006) at Giessen, Germany studied set of ninety six genotypes was characterised using publicly available mapped SSR markers spread over the Brassica napus genome. Allelic information from 30 SSR primer combinations amplifying 220 alleles at 51 polymorphic loci provided unique genetic fingerprints for all genotypes. UPGMA clustering enabled identification of four general groups with increasing genetic diversity as follows (1) spring oilseed and fodder; (2) winter oilseed; (3) winter fodder; (4) vegetable genotypes (Table 1).

Table.1 Detail about ISSR markers used for diversity analysis in toria

\begin{tabular}{|l|l|l|l|l|}
\hline Marker & Sequence & \# of bp & Tm & Yield \\
\hline UBC 807 & AGAGAGAGAGAGAGAGT & 17 & 42.5 & 14.6 \\
\hline UBC 810 & AGAGAGAGAGAGAGAGT & 17 & 42.9 & 21.8 \\
\hline UBC 812 & AGAGAGAGAGAGAGAGA & 17 & 44.3 & 18 \\
\hline UBC 815 & CTCTCTCTCTCTCTCTG & 17 & 44.9 & 83.3 \\
\hline
\end{tabular}


Fig.1 Dendrogram constructed using UPGMA based on Jaccard's coefficient of 24 Brassica compestris var. Toria genotypes (ISSR Markers)

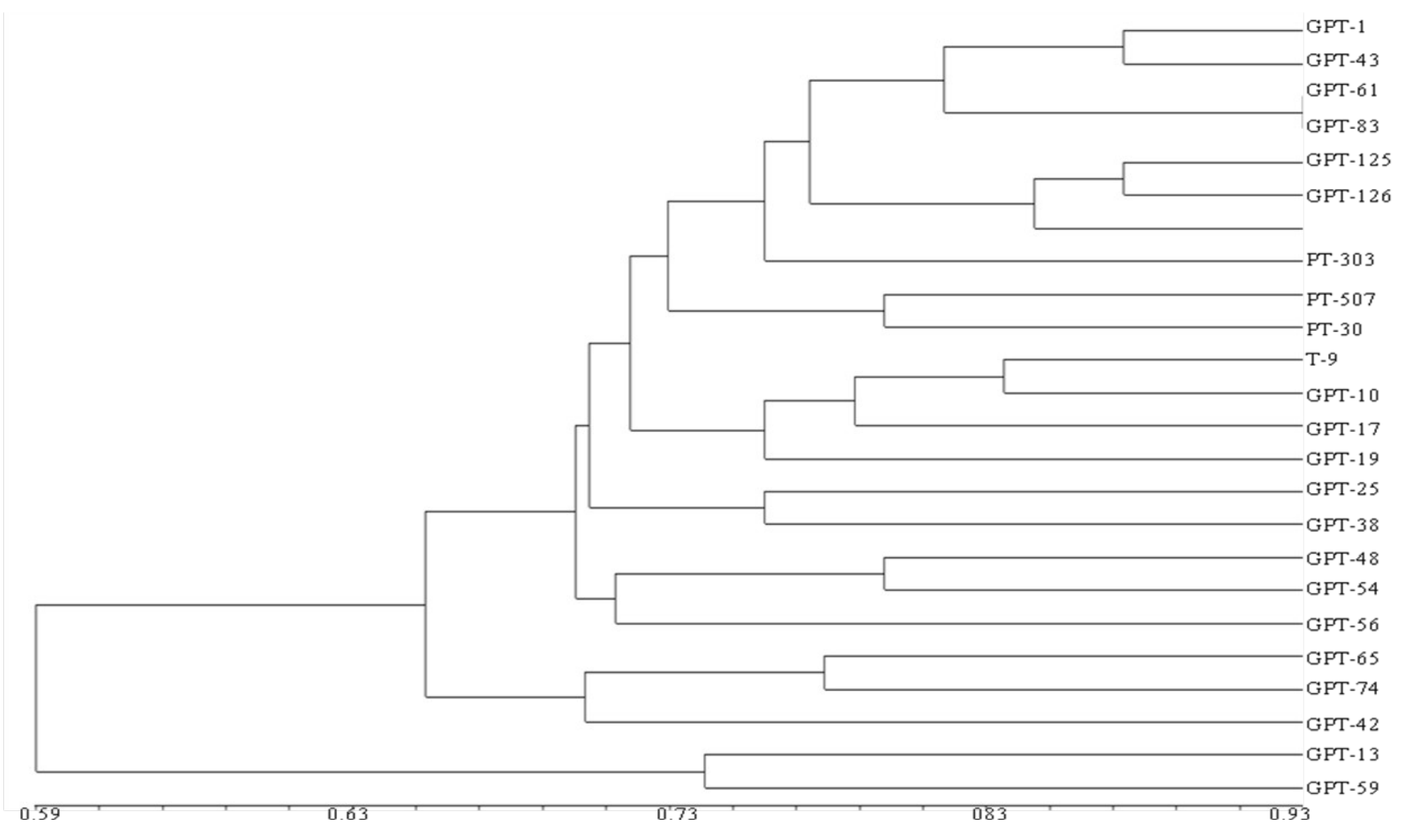


Fig.2 ISSR Profile generated by UBC 810, UBC 807, UBC 812 and UBC 815 primers of 24 Toria germplasm including varieties

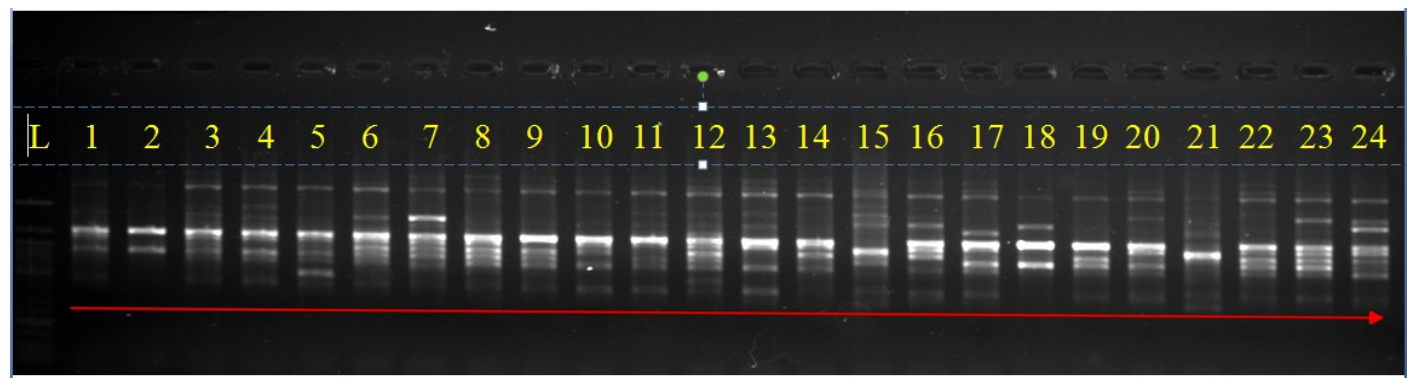

\section{UBC 810}

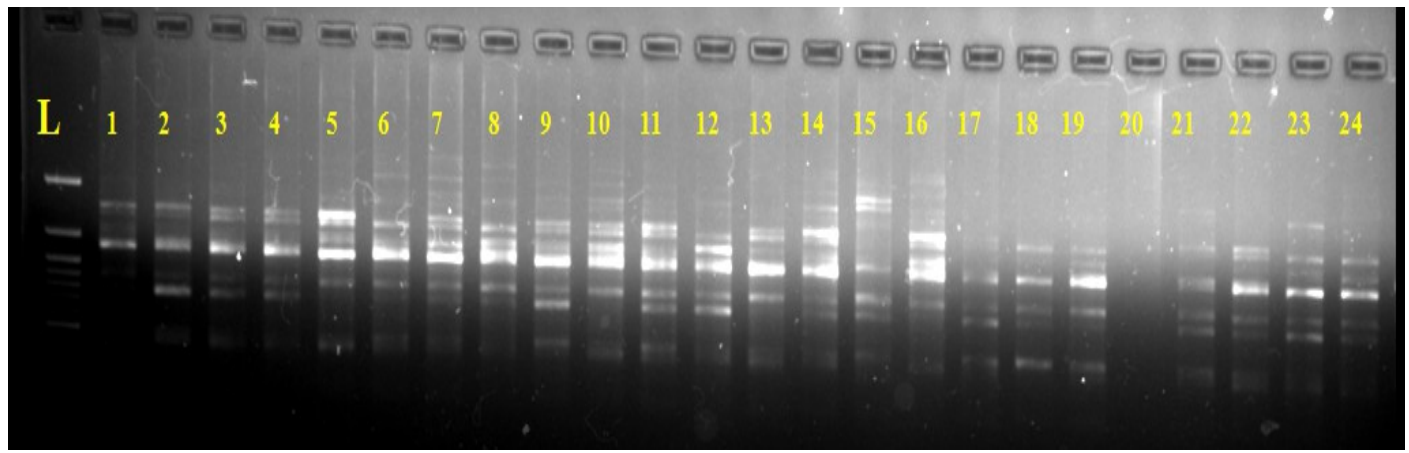

UBC 807

$\begin{array}{lllllllllllllllllllllllll}\mathrm{L} & 1 & 2 & 3 & 4 & 5 & 6 & 7 & 8 & 9 & 10 & 11 & 12 & 13 & 14 & 15 & 16 & 17 & 18 & 19 & 20 & 21 & 22 & 23 & 24\end{array}$

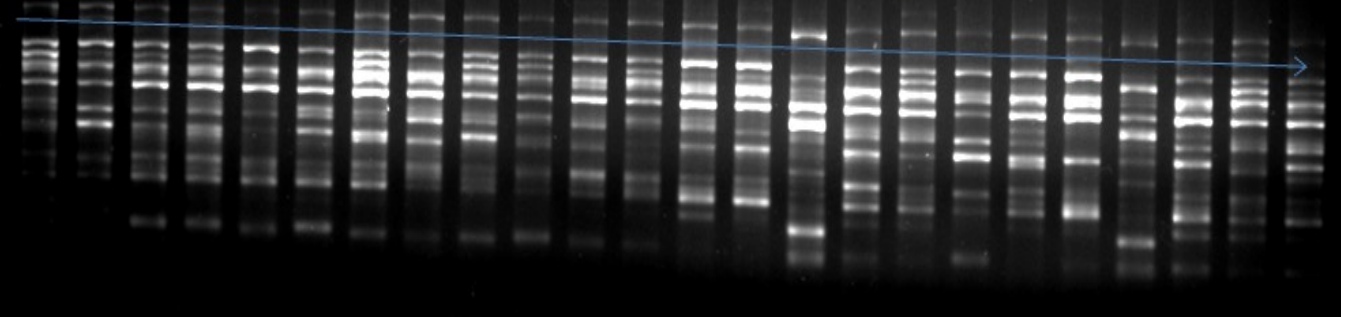

UBC 812

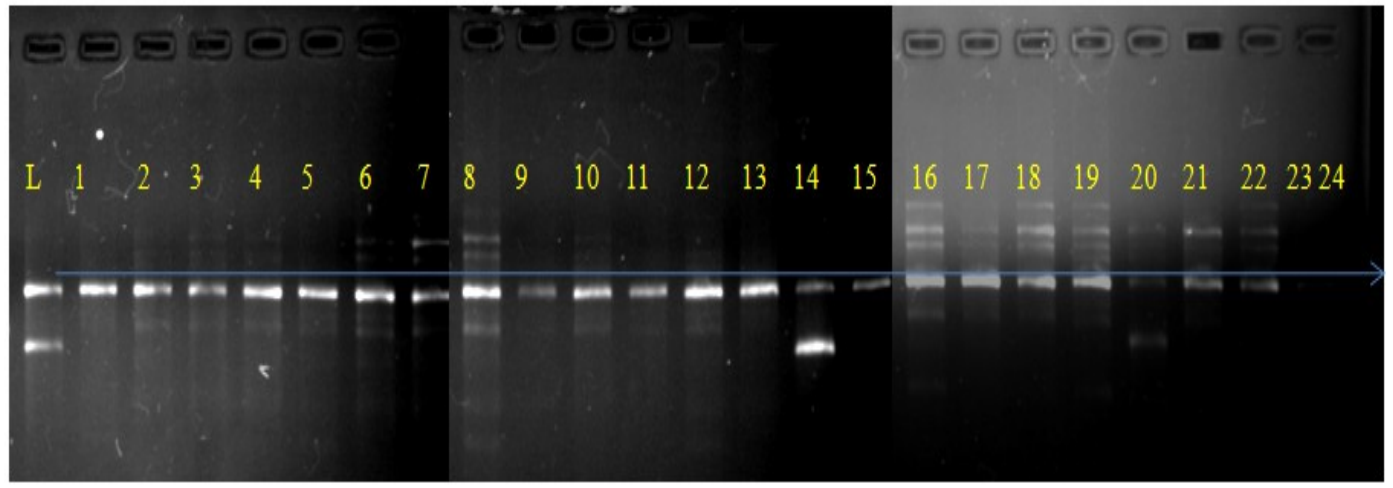

UBC 815 
These results indicated the existence of sufficient Variability among genotypes and there are very much chance of improvement either through selection or through hybridization by getting heterosis. This result also indicated that ISSR analysis is effective for the assessment of genetic diversity among Brassica compestris genotypes. A similarity matrix based on the proportion of shared ISSR fragments was used to establish the level of relatedness between the various collected toria genotypes. These results were further strengthened by the earlier findings of Yu et al., (2007), Abbas et al.(2009), Ghosh et al., (2009), Moghaddam et al., (2009), Villa et al., (2009), Ali et al., (2011), Das et al., (2011), Molla et al., (2011), Abtahi and Arzani (2013), Vinu et al., (2013), Tahira et al., (2014), Ahmad et al., (2014) and Iqbal et al., (2015).

\section{Acknowledgement}

I am immensely thankful to Dr. S.C. Mukherjee, Dean, S.G. College of Agriculture \& Research station, Jagdalpur (Chhattisgarh), India other technical and non-technical staff members of Department of Genetics and Plant Breeding, for their valuable suggestions, kind cooperation and encouragement during the investigation.

\section{References}

Abbas, H.G., Mahmood, A. and Ali, Q. 2015. An overview of genetic variability and gene action to improve yield of brassica napus. Nature and Science, 13(4): 28-35.

Abbas, S.J., Farhatullah, Marwat, K.B., Khan, I.A. and Munir, I. 2009. Molecular analysis of genetic diversity in Brassica species. J. Bot., 41(1): 167-176.

Abtahi, M. and Arzani, A. 2013. Molecular and morphological assessment of genetic variability induced by gamma radiation in canola. J. Pl. Mole. Breed., 1(2): 69-84.

Abtahi, M. and Arzani, A. 2013. Molecular and morphological assessment of genetic variability induced by gamma radiation in canola. J. Pl. Mole. Breed., 1(2): 69-84.

Ahmad, R., Farhatullah, Quiros, C.F., Rahman H. and Swati, Z.A. 2014. Genetic diversity analyses of Brassica napus accessions using SRAP molecular markers. Pl. Genet. Resour., 12 (01): 14-21.

Ali, A., Shokrpour, M., Chamanabad, H.M., Sofalian O. 2011. Evaluating genetic diversity of canola cultivars using morphological traits and molecular markers Romanian Biotechnological Letters. 16(4):6305-6312.

Das, R., Das, K., Barua, D.K. and Ray, A. 2001. Genetic variability in toria (Brassica campestris var toria). J. Oilseeds Res., 18 (1): 6-9.

Ghosh, K.K., Haque, M.E., Parvin, M.S., Akhter, F. and Rahim, M.M. 2009. Genetic diversity analysis in brassica varieties through RAPD markers. Bangladesh J. Agric. Res., 34(3): 493-503.

Iqbal, S. Hamim, I. Haque, S. and Nath, U. K.2015. Genetic diversity analysis of mustard (Brassica spp.) germplasm using molecular marker for selection of short duration genotypes. African J. Biotech. 14(17): 1439-1448

Jain, A., S. Bhatia, S. S Banga, S. Prakash and M. Lakshmi kumaran, 1994: Potential use of random amplified polymorphic DNA (RAPD) technique to study the genetic diversity in Indian mustard (Brassica juncea) and its relationship to heterosis. Theor Appl Genet 88, 116-122.

Khan, M. A., M. A. Rabbani, M. Munir, S. K Ajmal and M. A. Malik, 2008: Assessment of genetic variation within Indian mustard (Brassica juncea) germplasm using random amplified polymorphic DNA markers. Journal of Integrative Plant Biology 50, 385-392.

Moghaddam, M., Mohammmadi, S.A., Mohebalipour, N., Toorchi, M., Aharizad, S. and Javidfar, F. 2009. Assessment of genetic diversity in rapeseed cultivars as revealed by RAPD and microsatellite markers. Afr. J. Biotech., 8 (14): 31603167.

Molla, M.R., Islam, M.N., Rohman, M.M., Ahmed, I. and Rahman L. 2011. DNA 
fingerprinting of Rape seed (Brassica rapa L.) varieties of Bangladesh using SSR markers. Nature and Science, 9(5): 222228.

$\mathrm{Pu}, \mathrm{X}$., M. Wang, L. Luan, X. Wang, J. Zhang, H. Li, Q. Zhang, L. Yi, Y. Cao, L. Jiang and Y. Zhao, 2007: Genetic diversity analysis of Brassica juncea landraces in southwest China. Scientia Agricultura Sinica 40, 1610-1621.

Sheng Chen, Zhenjie Wan, Matthew N. Nelson, Jitendra S. Chauhan, Ping Lin, Bob Redden, Wayne A. Burton, Surinder Banga, Yuehua Chen, Phillip A. Salisbury, Tingdong $\mathrm{Fu}$ and Wallace A. Cowling 2011: Two distinct genetic diversity groups of oilseed Brassica juncea in both China and India $17^{\text {th }}$ Australian Research Assembly on Brassicas (ARAB) Wagga Wagga NSW August 2011. Pp. 20-23

Shiran, B., Azimkhani, R., Ahmadi, M.R. and Mohammadi S. 2004. Assessment of genetic diversity among rapeseed (Brassica napus L.) cultivars using random amplified polymorphic DNA (RAPD) analysis. Proceedings of the Fourth International Iran \& Russia Conference, 20-25.

Srivastava, A., V. Gupta, D. Pental and A. K. Pradhan, 2001: AFLP-based genetic diversity assessment amongst agronomically important natural and some newly synthesized lines of Brassica juncea Theor Appl Genet 102, 193-199.

Tahira, Rashid A., Khan, M.A. and Amjad M.
2014. Seed yield improvement in mustard [Brassica juncea (L.) Czern \& Coss] via genetic parameters; heritability, genetic advance, correlation and path coefficient analysis. Int. J. Agric. Innov. Res., 3(3): 2319-1473.

Villa, N. O., Celucia S. U. and Pena, R.C. de la (2009) Genetic Characterization of Brassica rapa chinensis L., $B$. rapa parachinensis (L. H. Bailey) Hanelt, and $B$. oleracea alboglabra (L. H. Bailey) Hanelt Using Simple Sequence Repeat Markers. Philip. J. of Sci., 138(2): 141-152.

Vinu, V., Singh, N., Vasudev, S., Yadava, D.K., Kumar, S., Naresh S., Bhat, S R. and Prabhu K.V. 2013. Assessment of genetic diversity in Brassica juncea (Brassicaceae) genotypes using phenotypic differences and SSR markers. Rev. Biol. Trop., 61(4): 1919-34.

Wu, X., B. Chen, G. Lu, H. Wang, K. Xu, G. Guizhan and Y. Song, 2009: Genetic diversity in oil and vegetable mustard (Brassica juncea) landraces revealed by SRAP markers. Genetic Resources and Crop Evolution, DOI 10.1007/s10722-0099420-8. Published online 17 March 2009.

Yu, C., Leisova L., Kucera V., vadilova, M.V., Ovesna J., Dotlacil, L. and Hu, S. 2007. Assessment of genetic diversity of yellowseeded rapeseed (Brassica napus L.) accessions by AFLP markers. Czech J. Genet. Pl. Breed., 43:(3): 105-112.

\section{How to cite this article:}

Salam, J.L., N. Mehta, A.K. Sarawagi, Ritu R. Saxena, S. Verulkar and Tomar, N. 2018. Genetic Diversity Analysis Based on Molecular Level in Selected Brassica compestris L. var. toria Genotypes. Int.J.Curr.Microbiol.App.Sci. 7(07): 3604-3611.

doi: https://doi.org/10.20546/ijcmas.2018.707.419 